\title{
Fraud Analysis of Financial Statements Based on the Fraud Triangle Method in BUMN Companies Listed on the IDX for the 2014-2018 Period
}

\author{
Jahrotun Annisa ${ }^{1}$, Ratna Ambar Mintarsih ${ }^{2}$ \\ Sekolah Tinggi Ilmu Ekonomi "YKP” Yogyakarta \\ \{ambarmint@gmail.com\}
}

\begin{abstract}
Fraud in financial statements can cause financial losses and decrease the level of trust of external parties in company performance. This study aims to determine the effect of variable financial stability, financial targets, industrial conditions, ineffective supervision and auditor turnover on fraudulent financial statements of state-owned companies listed on the IDX for the 2014-2018 period. This research is a type of quantitative research with the object of research on 11 state-owned companies listed on the IDX and publishing financial reports for 5 years of observation. The determination of the number of samples is based on the purposive sampling method. The data analysis method used was descriptive statistical test, classical assumption test, multiple linear regression test, $\mathrm{t}$ test, $\mathrm{F}$ test and determination test. The results showed that financial stability and ineffective supervision proved to have a significant effect on fraudulent financial statements with a significance value of 0.000 and 0.000 , respectively. Meanwhile, for financial targets, industrial conditions and auditor turnover, the significance values are $0.051,0.088$ and 0.637 , respectively, so it cannot prove that there is a significant effect on fraudulent financial statements. The simultaneous test results show a significance value of 0.000 , so there is a simultaneous influence on financial stability. The test of determination produces an $\mathrm{R}$ square value of 0.547 , this shows that fraudulent financial statements can be explained by financial targets, industrial conditions, ineffective supervision and auditor turnover, while $45.3 \%$ is explained by other variables not in this study.
\end{abstract}

Keywords: fraudulent financial statements, financial stability, financial targets, industrial conditions, ineffective supervision, auditor change.

\section{Introduction}

The financial report is a structured presentation of the report on the financial position and financial performance of an entity. Apart from the internal interests of a company, financial statements are also widely used by external parties in making decisions. Investors who will invest capital refer to the financial statements for their investment consideration. The large number of parties who use financial reports as a reference, of course, makes fraud in the preparation of financial reports an extremely prohibited thing to do. If there is writing in an 
incorrect financial report, whether intentional or unintentional, of course it will become a serious problem, Fraud in financial statements will of course also harm the company as an internal party which can ultimately have a negative impact on the sustainability of a company's performance, and result in the company experiencing a crisis. trust from investors and other external parties.

Rozmita (2017) defines fraud or "fraud" as an intentional act designed to benefit oneself or a group, and to harm others. Oriol Amat (2019) defines fraud as the act of deceiving someone to get unfair things or illegal profits. Based on several definitions of cheating that have been previously described, it can be concluded that cheating is an intentional act wherein the large Indonesian dictionary the word "deliberately" is defined as intended (planned). Thus, fraud is an illegal act that is not justified because it contains elements of deliberation and planning to harm other parties.

In general, financial statement fraud is one of the manipulative actions of management in preparing financial reports. Manipulation of financial statements will generally depict earnings that have increased from the previous year as evidence to investors that the company's operational activities are going well. For this reason, earnings management in this case is used as a proxy in detecting fraudulent financial statements. The earnings management action itself is said to be an act that is deliberately carried out by company management to regulate its financial statements to display maximum results in terms of profits.

In 1953, a criminologist Donald R Cressey then revealed a theory called the Fraud Triangle Theory where it is said that the party who commits fraud is based on three factors, namely Pressure, Opportunity and Rationalization. The theory was then developed by AICPA in 2002 into SAS No. 99. In SAS No. 99 explained that the situation resulting from the pressure is financial targets and financial stability. Opportunities with industrial conditions and ineffective supervision and rationalization with the change of auditors in a company.

Based on the explanation above, then the researcher is interested in conducting a study entitled "The Influence of the Influence of the Fraud Triangle Method on Financial Statement Fraud in BUMN companies listed on the IDX for the 2014-2018 period". This research aims to :

a. Knowing the significant effect of financial stability, financial targets, industrial conditions, ineffective supervision, changes in auditors on fraudulent financial statements.

b. Knowing the significant effect of financial stability, financial targets, industry conditions, ineffective supervision, and changes in auditors simultaneously on fraudulent financial statements.

\section{Theoretical Basis}

Forensic accounting is the application of a scientific discipline in a broad sense which includes auditing to solve legal problems related to accounting in general, inside or outside the court, in the public and private sectors (Tuanakota: 2010 in Rika: 2016).

\subsection{Definition of Fraud}

The Oxford Dictionary defines Fraud as a wrong act or a criminal act committed for personal gain. Rozmita (2018) defines fraud as fraud with the aim of gaining profit, avoiding obligations or harming other parties. 
In general, fraud can be interpreted as an act that is done by certain parties on purpose to get something that is used for personal gain and to harm other parties.

\subsection{Fraud Triangle Theory}

The Fraud Triangle Theory is a theory put forward in 1953 by a criminologist named Donald R Cressey. Donald R Cressey said that there are 3 factors that cause certain parties to be motivated to commit fraud, namely Pressure, Opportunity and Rationalization.

\subsection{Schematic of Fraud Triangle Theory Development}

After Donald R Cressey put forward the Fraud Triangle Theory, the theory was developed by several accounting experts (Aicpa) and followed by the emergence of various studies aimed at proving this Fraud Triangle Theory. In general, the Fraud Triangle Theory development scheme can be described as follows:

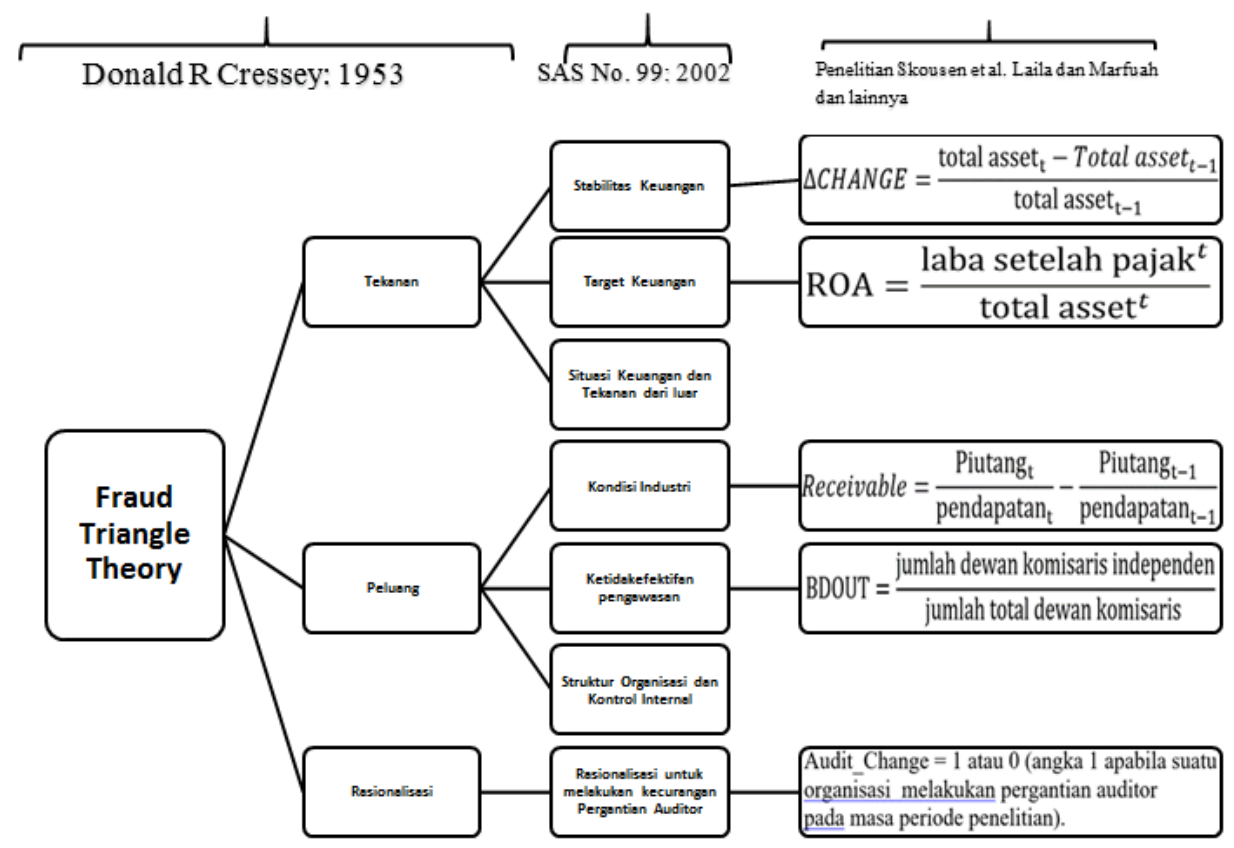

Fig 1. the Fraud Triangle Theory

\subsection{Research Hypothesis}

H1: It is suspected that financial stability has a significant effect on the existence of financial statement fraud.

$\mathrm{H} 2$ : It is suspected that financial targets have a significant effect on the existence of financial statement fraud.

H3: It is suspected that industrial conditions have a significant effect on the existence of fraud in financial statements. 
H4: It is suspected that the ineffectiveness of supervision has a significant effect on the existence of fraudulent financial statements.

H5: It is suspected that the change of auditors has a significant effect on the existence of fraudulent financial statements

\section{Research methods}

This type of research is a quantitative research, where the data to be studied are published during the research period. The research population is state-owned companies in Indonesia. The research sample was determined by purposive sampling method and produced 11 companies that match the predetermined crteria. The data in this study are sourced from financial statements taken from the Indonesia Stock Exchange and then processed according to the needs of research calculations. Operational definition of research variables

a. Fraudulent Financial Statements use the method of calculating earnings management (dicretionary accruals). Earnings management is carried out with the aim of tricking the users of financial statements by manipulating company profits

b. Financial Stability uses the method of calculating change in assets ( $\Delta$ change).

c. Financial Targets using the Return On Assets (ROA) calculation method

d. Industrial conditions using the Receivable calculation method

e. Supervision is ineffective using the method of calculating the number of independent boards of commissioners (BDOUT)

f. Auditor turnover uses a numeric scale method, namely 1 for those who did change auditors and 0 for those who did not change auditors.

The data analysis methods used in this research include descriptive statistical test, classical assumption test, multiple regression analysis, hypothesis testing and determination test (R2).

\section{Results and Discussion}

This research was conducted with the object of research for BUMN companies in the service sector listed on the IDX and publishing financial reports during the 2014-2018 period. In its important role as a support agent of development, BUMN consists of 114 companies and is divided into several sectors, including the service sector. Determination of the number of samples is determined by purposive sampling method, namely determining the sample with certain criteria. The criteria that have been determined include:
a. Research companies are included in state-owned companies
b. The company is listed on the Indonesia Stock Exchange
c. The company published financial reports during 2014-2018
d. The company is included in the service sector company.

The following is a list of state-owned companies that meet the above criteria:

Table 1. BUMN Company

\begin{tabular}{|c|c|}
\hline BUMN company & Stock code \\
\hline PT Adhi Karya (Persero), Tbk. & ADHI \\
\hline PT Bank BNI (Persero), Tbk. & BBNI \\
\hline PT Bank BRI (Persero), Tbk. & BBRI \\
\hline PT Bank BTN (Persero), Tbk. & BBTN \\
\hline
\end{tabular}




\begin{tabular}{lc}
\hline \multicolumn{1}{c}{ BUMN company } & Stock code \\
\hline PT Bank Mandiri (Persero), Tbk. & BMRI \\
PT Garuda Indonesia (Persero), Tbk. & GIAA \\
PT Jasa Marga (Persero), Tbk. & JSMR \\
PT Pembangunan Perumahan (Persero), Tbk. & PTPP \\
PT Telkom (Persero), Tbk. & TLKM \\
PT Waskita Karya (Persero), Tbk. & WSKT \\
PT Wijaya Karya (Persero), Tbk. & WIKA \\
\hline
\end{tabular}

\subsection{Descriptive Statistical Test}

The results of descriptive test analysis can be seen in table 2:

Table 2. Descriptive Statistical Test

\begin{tabular}{|c|c|c|c|c|c|}
\hline & $\mathrm{N}$ & Minimum & Maximum & Mean & Std. Deviation \\
\hline DAit & 55 & $-0,01154$ & 0,03997 & 0,0130375 & 0,01066063 \\
\hline$\Delta$ CHANGE(X1) & 55 & 0,01248 & 0,58620 & 0,1859125 & 0,11652023 \\
\hline ROA(X2) & 55 & $-0,11850$ & 0,16475 & 0,0329415 & 0,04483400 \\
\hline Receivable(X3) & 55 & $-1,12137$ & 1,05903 & 0,0464700 & 0,36242603 \\
\hline BDOUT(X4) & 55 & 0,28571 & 0,62500 & 0,4283117 & 0,11064460 \\
\hline Aud_Change(X5) & 55 & 0 & 1 & 0,29 & 0,458 \\
\hline Valid N (listwise) & 55 & & & & \\
Sumber : Data Output SPSS Ver.25
\end{tabular}

From the table above it can be concluded

a) Financial Statement Fraud has the lowest value of -0.01154 , the largest value of 0.03997 , an average value of 0.01303 and a standard deviation of 0.01066 .

b) Financial Stability has the lowest value of 0.01248 , the largest value of 0.5862 , an average value of 0.1859 and a standard deviation of 0.11652 .

c) The Financial Target has the lowest value of -0.1185 , the largest value of 0.16475 , an average value of 0.0329 and a standard deviation of 0.04483 .

d) Industrial conditions have the lowest value of -1.1213 , the largest value of 1.0590 , an average value of 0.0464 and a standard deviation of 0.3624 .

e) The ineffectiveness of supervision has the lowest value of 0.2857 , the largest value of 0.6250 , an average value of 0.4283 and a standard deviation of 0.1106 .

f) Supervision ineffectiveness has the lowest value of 0 , the largest value of 1 , the average value of 0.29 and the standard deviation of 0.458 .

\subsection{Classical Assumption Test, Consisting}

Normality test: normally distributed because the significance value $>0.000$

Table 3. Normality test

\begin{tabular}{|c|c|}
\hline & Unstandardized Residual \\
\hline $\mathrm{N}$ & 55 \\
\hline Asymp. Sig. (2-tailed) &, 200 \\
\hline
\end{tabular}


Multicolloniearity Test: Multicolloniearity does not occur because the tolerance value is $>$ 0.01

Table 4. Multicolloniearity Test

\begin{tabular}{|c|c|c|c|}
\hline \multirow{2}{*}{ Model } & \multicolumn{2}{|c|}{ Collinearity Statistics } & \multirow{2}{*}{ Kesimpulan } \\
\hline & Tolerance & VIF & \\
\hline$\triangle \mathrm{CHANGE}(\mathrm{X} 1)$ & 0,756 & 1,323 & Tidak terjadi multikoloniearitas \\
\hline $\mathrm{ROA}(\mathrm{X} 2)$ & 0,991 & 1,009 & Tidak terjadi multikoloniearitas \\
\hline Receivable(X3) & 0,969 & 1,032 & Tidak terjadi multikoloniearitas \\
\hline BDOUT(X4) & 0,758 & 1,318 & Tidak terjadi multikoloniearitas \\
\hline Aud_Change(X5) & 0,826 & 1,211 & Tidak terjadi multikoloniearitas \\
\hline
\end{tabular}

Autocorrelation test: autocorrelation does not occur because the value of $\mathrm{du}<\mathrm{dw}<4$-du $=$ $1.374<2,216<2,232$

Table 5. Autocorrelation test

\begin{tabular}{|l|c|r|r|r|r|}
\hline Model & $\mathrm{R}$ & R Square & Adjusted R Square & Std. Error of the Estimate & Durbin-Watson \\
\hline 1 &, $740^{\mathrm{a}}$ & 0,547 & 0,501 & 0,00753164 & 2,216 \\
\hline
\end{tabular}

Heteroscedasticity test: No signs of heteroscedasticity occurred because the significance value was $>0.05$

Table 6. Heteroscedasticity test

\begin{tabular}{|c|c|c|c|c|}
\hline & \multirow{2}{*}{ Model } & Standardized Coefficients & \multirow[b]{2}{*}{$\mathrm{t}$} & \multirow{2}{*}{ Sig. } \\
\hline & & Beta & & \\
\hline \multirow{6}{*}{1} & (Constant) & & 1,278 & ,207 \\
\hline & $\triangle \mathrm{CHANGE}(\mathrm{X} 1)$ & 073 & , 477 & ,635 \\
\hline & $\mathrm{ROA}(\mathrm{X} 2)$ &,- 168 & $-1,234$ & ,223 \\
\hline & Receivable(X3) & ,120 & ,871 & ,388 \\
\hline & $\operatorname{BDOUT}(\mathrm{X} 4)$ &,- 019 &,- 123 &, 902 \\
\hline & LogX5 & ,244 & 1,689 & ,098 \\
\hline
\end{tabular}

Multiple Regression Analysis:

Table 7. Multiple Regression Analysis

\begin{tabular}{|c|c|c|c|c|c|c|}
\hline & \multirow[t]{2}{*}{ Model } & \multicolumn{2}{|c|}{$\begin{array}{l}\text { Unstandardized } \\
\text { Coefficients }\end{array}$} & \multirow{2}{*}{$\begin{array}{c}\begin{array}{c}\text { Standardized } \\
\text { Coefficients }\end{array} \\
\text { Beta }\end{array}$} & \multirow[t]{2}{*}{$\mathrm{t}$} & \multirow[t]{2}{*}{ Sig. } \\
\hline & & $B$ & Std. Error & & & \\
\hline \multirow[t]{6}{*}{1} & (Constant) & $-0,021$ & 0,006 & & $-3,614$ & 0,001 \\
\hline & $\triangle \mathrm{CHANGE}(\mathrm{X} 1)$ & 0,062 & 0,010 & 0,680 & 6,148 & 0,000 \\
\hline & $\mathrm{ROA}(\mathrm{X} 2)$ & $-0,046$ & 0,023 & $-0,193$ & $-2,003$ & 0,051 \\
\hline & Receivable(X3) & 0,005 & 0,003 & 0,170 & 1,740 & 0,088 \\
\hline & BDOUT(X4) & 0,056 & 0,011 & 0,578 & 5,236 & 0,000 \\
\hline & Aud Change(X5) & $-0,001$ & 0,002 & $-0,050$ & $-0,474$ & 0,637 \\
\hline
\end{tabular}

Based on the table of multiple linear regression test results, the regression equation is obtained as follows: $\mathrm{Y}=-0.021+0.062 \mathrm{X} 1+-0.046 \mathrm{X} 2+0.005 \mathrm{X} 3+0.056 \mathrm{X} 4+-0.001 \mathrm{X} 5$

\subsection{Hypothesis testing}




\section{a) Partial (t test)}

The $t$ test results show that there are 2 variables with a significance value $<0.005$, namely $\mathrm{X} 1$ (financial stability) and X4 (ineffective supervision). It can be concluded that H1 and H4 are accepted. This means that financial stability and ineffective supervision have a significant effect on fraudulent financial statements. $\mathrm{H} 2, \mathrm{H} 3$ and $\mathrm{H} 5$ are rejected because the significance value is $>0.005$, which means that financial targets, industry conditions and auditor turnover have no effect on fraudulent financial statements.

Table 8. Partial ( $\mathrm{t}$ test)

\begin{tabular}{|c|c|c|c|c|c|c|}
\hline \multirow{2}{*}{\multicolumn{2}{|c|}{ Model }} & \multicolumn{2}{|c|}{$\begin{array}{l}\text { Unstandardized } \\
\text { Coefficients }\end{array}$} & \multirow{2}{*}{$\begin{array}{c}\text { Standardized } \\
\text { Coefficients } \\
\text { Beta }\end{array}$} & \multirow[t]{2}{*}{$\mathrm{t}$} & \multirow[t]{2}{*}{ Sig. } \\
\hline & & B & Std. Error & & & \\
\hline \multirow[t]{6}{*}{1} & (Constant) & $-0,021$ & 0,006 & & $-3,614$ & 0,001 \\
\hline & $\triangle \mathrm{CHANGE}(\mathrm{X} 1)$ & 0,062 & 0,010 & 0,680 & 6,148 & 0,000 \\
\hline & $\mathrm{ROA}(\mathrm{X} 2)$ & $-0,046$ & 0,023 & $-0,193$ & $-2,003$ & 0,051 \\
\hline & Receivable(X3) & 0,005 & 0,003 & 0,170 & 1,740 & 0,088 \\
\hline & BDOUT(X4) & 0,056 & 0,011 & 0,578 & 5,236 & 0,000 \\
\hline & Aud_Change(X5) & $-0,001$ & 0,002 & $-0,050$ & $-0,474$ & 0,637 \\
\hline
\end{tabular}

\section{b) Simultaneous Test (Test F)}

Simultaneously, all research variables have an effect on variable $Y$ because the significance value in the SPSS data output shows a value of 0,000 or a significance value of $<0.005$, so that H6 is accepted. This shows that financial stability, financial targets, industrial conditions, ineffective supervision and auditor turnover together have a significant effect on the existence of fraudulent financial statements.

Table 9. Simultaneous Test (Test F)

\begin{tabular}{|c|c|c|c|c|c|c|}
\hline \multicolumn{2}{|c|}{ Model } & $\begin{array}{c}\text { Sum of } \\
\text { Squares }\end{array}$ & Df & $\begin{array}{c}\text { Mean } \\
\text { Square }\end{array}$ & F & Sig. \\
\hline \multirow{3}{*}{1} & Regression & 0,003 & 5 & 0,001 & 11,838 &, $000^{\mathrm{b}}$ \\
\cline { 2 - 7 } & Residual & 0,003 & 49 & 0,000 & & \\
\cline { 2 - 7 } & Total & 0,006 & 54 & & & \\
\hline
\end{tabular}

\section{c) Determination Test (R2)}

The results of the determination test obtained an $\mathrm{R}$ Square value of 0.547 or $54.7 \%$ indicating that financial stability, financial targets, industrial conditions, ineffectiveness of supervision and changes in research auditors only affect financial statement fraud by $54.7 \%$ while the remaining $46.3 \%$ is influenced by variables. other than this research. 
Table 10. Determination Test (R2)

\begin{tabular}{|l|r|c|r|r|}
\hline Model & R & R Square & Adjusted R Square & Std. Error of the Estimate \\
\hline 1 &, $740^{\mathrm{a}}$ &, 547 &, 501 &, 007531639911627 \\
\hline
\end{tabular}

Citations. For citations in the text use consecutive numbers in square brackets: [1], [2], [3], etc.

\section{Conclusion}

a. Financial stability, which is proxied by using changes in assets, has a significant effect on fraudulent financial statements with a significance value of 0.000 . This shows that changes in assets can put pressure on management to manipulate financial reports so that changes in assets can be used as an indicator to see financial statement fraud.

b. Financial targets that are proxied using ROA have no significant effect on financial statement fraud with a value of 0 . This means that the ROA ratio cannot put pressure on management to commit fraud so that ROA cannot be used as an indicator of financial statement fraud.

c. Industrial conditions with a significance value of 0.088 represented by Receivable as a proxy have no significant effect on fraudulent financial statements. Management does not view receivables as an opportunity to manipulate financial statements. So it can be concluded that industrial conditions cannot be used as an indicator to see the existence of fraudulent financial statements

d. The ineffectiveness of supervision has a significant effect on the existence of fraudulent financial statements with a significance value of 0.000 . The number of boards of commissioners can be used as an opportunity for management to commit fraud in financial reports, so that ineffective supervision can be used as an indicator for the detection of financial statement fraud.

e. The change of auditors has no significant effect on fraudulent financial statements with a significance value of 0.637 . The change of auditors cannot be used as a management justification for committing fraud in financial statements and indicators for detection of financial report fraud.

f. Financial stability, financial targets, industrial conditions, ineffective supervision and auditor changes together have a significant effect on the existence of fraudulent financial statements with a significance value of 0.000 .

g. Financial stability, financial targets, industrial conditions, ineffective supervision and a change in research auditors only affected the fraudulent financial statements of $54.7 \%$, while the remaining $46.3 \%$ was influenced by other variables outside of this study.

\section{Acknowledgements}

The heading should be treated as a $3^{\text {rd }}$ level heading and should not be assigned a number

\section{References}


[1] Abdullahi, Rabi'u. dan Mansor, Noorhayati.. Fraud Triangle Theory and Fraud Diamond Theory. Understanding the Convergent for Future Research. Journal of Academic Research in Accounting, Finance and Management Sciences, Vol 5 No.4.(2015)

[2] ACFE Indonesia.Survai Fraud Indonesia. . (2016).

[3] ACFEFraud Resources : Fraud 101. (2004).

[4] Albrecht, W Steve., Albrecht, Conan C., Albrecht, Chad O.. Fraud Examination $2^{N D}$ Edition. Canada : Thomson South Western. (2006)

[5] Albrecht, W.S., Wernz, G. W., Williams, T. L..Fraud : bringing light to the dark side of business. New York: Irwin Profesional Publishing. (1995)

[6] Amat, Oriol. Detecting Accounting Fraud before it's too late. Canada : John Wiley \& Sons, Inc(2019).

[7] Andri Susanti, Yayuk. Pendeteksian Kecurangan Laporan Keuangan.Skripsi. Fakultas Ekonomi dan Bisnis.Universitas Airlangga, Surabaya. ( 2014)

[8] Committee of Sponsoring Organisations of the Tradeaway Comission. Fraud Risk Management guide.( 2016.)

[9] Davia, H. R., Coggins, P. C., Wideman, J.C., Kastantin, J. T.. Accountant's Guide To Fraud Detection and Control. New York : John Wiley \& Sons, Inc. (2000)

[10] Irianto, Gugus., dan Novianti, Nurlita..Dealing with Fraud.Malang : UB Press. (2018)

[11] Republik Indonesia. Undang - Undang No. 31 Tahun 1999 Tentang Pemberantasan Tindak Korupsi. Lembaran Negara Republik Indonesia Tahun 1999, No.3874. Sekretariat Negara. Jakarta. (1999.)

[12] Rika, Lidiah.. Korupsi dan Akuntansi Forensik. Journal Finance, Vol.2 No.2( 2016)

[13] Rozmita, D.. Fraud Penyebab dan pencegahannya. Bandung : Alfabeta.( 2017)

[14] Skousen et al.. Detecting and predicting financial statement fraud: The effectiveness of the fraudtriangle and SAS No. 99. Journal Advances in Financial Economics, Volume 13, 53-81. (2009)

[15] Sugiyono. Metode penelitian Kuntitatif Kualitatif dan R\&D. Bandung : Alfabeta. (2009).

[16] Suliyanto.. Ekonometrika Terapan : Teori dan Aplikasi dengan SPSS. Yogyakarta: CV Andi Offset. (2011)

[17] Suryandari, Ni Nyoman Ayu. Yuesti, Anik. Suryawan, I Made.. Fraud Risk and Earning Management. Journal of Management Policies and Practicies, Vol. 7 No.1. (2019)

[18] Tiffani.dan Marfuah.. Deteksi financial statement fraud dengan analisis fraud triangle pada perusahaan manufaktur yang terdaftar di bursa efek Indonesia.Jurnal Akuntansi dan Auditing Indonesia, Vol. 19 (2). (112-125) (2015)

[19] Triponika Sari, Selni. Pengaruh Financial Stability, External Pressure, Financial Targets, Ineffective Monitoring, Rationalization Pada Financial Statement Fraud Dengan Perspektif Fraud Triangle . Jurnal Online Mahasiswa,Fakultas Ekonomi, Vol. 3 No. 1(2016).

[20] Wahyuni.dan Budiwitjaksono. Fraud Triangle Sebagai Pendeteksi Kecurangan Laporan Keuangan. Jurnal Akuntansi, Vol 11 (1). 47-61(2017).

[21] Zabihollah, razaee. 2002. financial statement fraud financial. New york. John wiley \& Son Inc. https://books.google.co.id/ diakses pada 15 februari (2020) 
